\title{
CINEMATEXAS NOTES
}



CinemaTexas
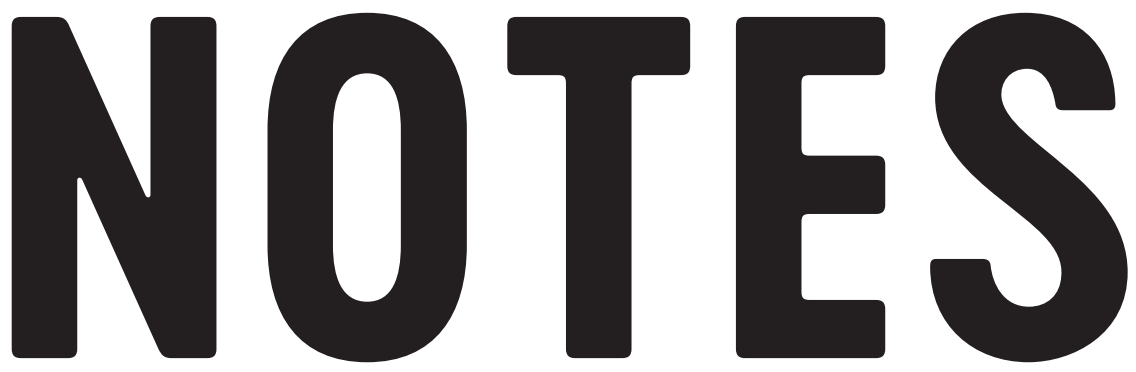

The Early Days of Austin Film Culture

\section{EDITED BY \\ LOUIS BLACK \\ WITH COLLINS SWORDS}

UNIVERSITY OF TEXAS PRESS $\mathbf{v}$ AUSTIN 
Copyright (C) 2018 by the University of Texas Press

All rights reserved

Printed in the United States of America

First edition, 2018

Requests for permission to reproduce material

from this work should be sent to:

Permissions

University of Texas Press

P.O. Box 7819

Austin, TX 78713-7819

utpress.utexas.edu/rp-form

@ The paper used in this book meets the minimum requirements of ANSI/NISO Z39.48-1992 (R1997)

(Permanence of Paper).

Library of Congress Cataloging-in-Publication Data

Names: Black, Louis, 1950-editor. | Swords,

Collins, editor. |University of Texas at Austin.

Department of Radio-Television-Film.

Title: CinemaTexas notes : the early days of Austin film culture / edited by Louis Black with Collins Swords.

Description: First edition. | Austin : University of Texas Press, 2018. | Includes bibliographical references and index.

Identifiers: LCCN 2017030872

ISBN 978-1-4773-1543-9 (cloth : alk. paper)

ISBN 978-1-4773-1544-6 (pbk. : alk. paper)

ISBN 978-1-4773-1545-3 (library e-book)

ISBN 978-1-4773-1546-0 (non-library e-book)

Subjects: LCSH: Motion pictures-Texas-Austin. | Motion pictures-Texas-History. | Culture in motion pictures.

Classification: LCC PN1993.5.U78 C56 2018 | DDC 791.430976431-dc23

LC record available at https://lccn.loc.gov $/ 2017030872$

doi:10.7560/315439 
Dedicated to Ed Lowry, our editor, teacher, fellow Program Note writer, mentor, and friend, who personified the best of CinemaTexas!

And to those no longer with us but much missed: Brian Hansen, Chuck Shapiro, Rita TheBerge, David Boone, Brent Grulke, and Richard Dorsett 
THIS PAGE INTENTIONALLY LEFT BLANK 